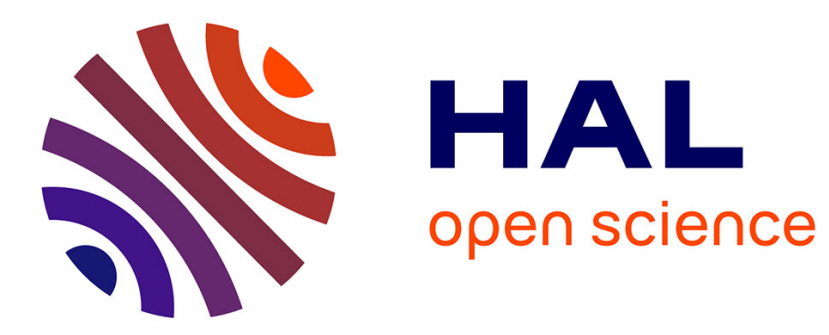

\title{
Housing wealth accumulation: The role of public housing
}

Florence Goffette-Nagot, Modibo Sidibé

\section{To cite this version:}

Florence Goffette-Nagot, Modibo Sidibé. Housing wealth accumulation: The role of public housing. 2014. halshs-00925717

\section{HAL Id: halshs-00925717 https://shs.hal.science/halshs-00925717}

Preprint submitted on 8 Jan 2014

HAL is a multi-disciplinary open access archive for the deposit and dissemination of scientific research documents, whether they are published or not. The documents may come from teaching and research institutions in France or abroad, or from public or private research centers.
L'archive ouverte pluridisciplinaire HAL, est destinée au dépôt et à la diffusion de documents scientifiques de niveau recherche, publiés ou non, émanant des établissements d'enseignement et de recherche français ou étrangers, des laboratoires publics ou privés. 
Housing wealth accumulation:

The role of public housing

Florence Goffette-Nagot, Modibo Sidibé

December 2013 


\section{GATE Groupe d'Analyse et de Théorie Économique Lyon-St Étienne}

93, chemin des Mouilles 69130 Ecully - France

Tel. +33(0)4 72866060

Fax $+33(0) 472866090$

6, rue Basse des Rives 42023 Saint-Etienne cedex 02 - France

Tel. +33 (0)4 77421960

Fax. +33 (0)4 77421950

Messagerie électronique / Email : gate@gate.cnrs.fr

Téléchargement / Download : http://www.gate.cnrs.fr - Publications / Working Papers 


\title{
Housing wealth accumulation: The role of public housing *
}

\author{
Florence Goffette-Nagot! , Modibo Sidibé $\ddagger$
}

November 2013

\begin{abstract}
The public housing sector provides housing units at below-market rents, potentially allowing its tenants to save for a downpayment more quickly than they would have otherwise. In this paper, we analyze the effect of a spell in public housing on age at first-time homeownership using the French Housing Survey. We use a pseudo-panel approach that takes into account the specificities of the local housing market, to derive individual tenure transitions from multiple cross-sections data. Using an IV strategy to control for a potential selection into public housing, we jointly estimate public housing tenancy and duration before first-time homeownership, and take into account unobserved heterogeneity. Our results indicate that a spell in public housing increases the hazard to homeownership, supporting the idea that, in France, the public housing policy provides an important pathway to homeownership.
\end{abstract}

Keywords: Homeownership, Public housing, Tenure choice, Duration model, Unobserved heterogeneity.

JEL Codes: R21, R31, R38, C41.

*This research uses confidential location data from the French Housing Survey. We thank the French Institute of Statistics (INSEE), and more precisely Catherine Rougerie, for the access to the French Housing Survey through the "Centre d'Accès Securisé Distant" (CASD) dedicated to researchers authorized by the French "Comité du secret statistique". We also thank Christian Hilber for insightful comments and seminar participants at Queens, Dijon and Lyon, as well as conference participants at the 57th North American Meetings of the Regional Science Association International and at the 59th Congress of the French Economics Association (AFSE).

${ }^{\dagger}$ CNRS, GATE LS-E; Université de Lyon, Lyon, F-69007, France; CNRS, GATE Lyon Saint-Etienne, Ecully, F-69130, France. Email: goffette-nagot@gate.cnrs.fr. Corresponding author.

${ }^{\ddagger}$ Duke University; Department of Economics, Duke University, United States. Email: modibo.sidibe@duke.edu 


\section{Introduction}

In most European countries, a strong public housing sector provides cheap and good quality housing to a substantial share of the population. Although the scope and the implementation of the policy vary across countries, its purpose is always to ensure minimal housing conditions to all households. There is no consensus on the effect of this policy, since the literature has provided evidence of both positive and negative externalities on individual outcomes. ${ }^{1}$

This paper provides an empirical test of the existence of an interplay between a spell in public housing and the homeownership decision. In particular, we study the effect of a spell in public housing on age at first-time homeownership.

This question is of particular interest in France where the public housing sector represents $37 \%$ of the rental housing stock, and shelter more than 10 millions of people (a sixth of the total population). In contrast to the US, French public housing tenants are not trapped in this segment of the housing market. ${ }^{2}$ One of the key feature of public housing in France is the level of rents, which are on average $40 \%$ below market prices. What remains unclear is how the induced welfare gain influences households' consumption and saving behavior. Le Blanc and Laferrère (2001) find that tenants in public housing consume more than their counterparts in private renting, with $10 \%$ more of housing services and $11 \%$ more of other goods. These welfare gains might be large since the eligibility conditions exclude only the $30 \%$ richest households. Given this effect on consumption, one could also suspect a positive effect on savings. If this were true,

\footnotetext{
${ }^{1}$ Fertig and Reingold (2007) test the existence of an effect of public housing on health. Currie and Yelowitz (2000) show that the seemingly negative effect of public housing on individual outcomes is driven by unobserved heterogeneity. Once controlled for this unobserved element, they show that public housing decreases the likelihood to live in overcrowded housing and children are less likely to have been held back at school. Newman and Harkness (2002) show that on the long run, children who have grown up in public housing tend to fare better as adults, which could be interpreted as the consequences of improved housing conditions and increased expenditures on items that benefit children development. Jacob (2004) finds no direct effect of public housing on student outcomes in Canada, although there is an indirect negative effect through the concentration of public housing in deprived neighborhood. Reingold et al. (2001) find similar results for the effect of public housing on social capital investment and labor participation in the US. As to labor-market outcomes, Currie and Yelowitz (1998) and de Graaff et al. (2009) find negative effects of public housing. Using French data, Dujardin and Goffette-Nagot (2009) show that public housing has no direct effect on unemployment risk, even tough the concentration of public housing in deprived neighborhood may alter the public tenants' long term career opportunity.

${ }^{2}$ The annual mobility rate of public tenants is around $8 \%$, close to the rate of $8.7 \%$ observed for the general population (Source: French Housing Survey). In terms of transition, more than one out of four of mobile public housing renters make a transition to homeownership.
} 
a spell in public housing might increase the household's ability to constitute a downpayment and hence foster homeownership attainment. As a consequence, the public housing policy might be an instrument indirectly promoting homeownership.

The effect of public housing on savings may be tempered by negative externalities effects on individuals' labor market outcomes. As shown by de Graaff et al. (2009) on European data, public housing tenants are less mobile on the labor market because of higher mobility costs and have therefore less job opportunities. Furthermore, the remote location of public housing often results in lower employment levels due to spatial mismatch. Finally, the social composition of public housing projects could generate negative neighborhood effects, and public housing could hence constitute a poverty trap. The existence of positive and negative impacts leaves undecided the final effect of a spell in public housing on subsequent homeownership attainment.

Using repeated cross-sections from the French Housing Survey (FHS, hereafter), we create a panel data of both households and housing characteristics. We jointly estimate age at first-time homeownership and the probability of a previous spell in public renting. We control for selfselection into public housing using an IV strategy based on the share of public housing within rental housing in the urban area. We introduce unobserved heterogeneity to account for any remaining correlation between previous tenure and age at first-time homeownership. Following Heckman and Singer (1984), we adopt a discrete distribution approach to limit the effects of distributional assumptions on estimation results.

Our results show that public housing plays a role in helping some households achieve homeownership, supporting the idea that the public housing fosters the housing wealth of some part of the population, speeding up transition to homeownership.

The rest of the paper is structured as follows. Section 2, we present the econometric model and the identification conditions. Section 3 is devoted to the data and the pseudo-panel procedure. In section 4, we provide some descriptive statistics and our estimation results. The last section concludes. 


\section{Estimation Strategy}

We propose an analysis of the duration before first-time homeownership controlling for a potential preceding spell in public housing. To do so, we estimate jointly a logistic model for the existence of a spell in public housing and a duration model of age at homeownership. Our joint model is designed to correct for a potential self-selection into public housing. The logit equation controls for the probability to have been a public tenant, while the duration model estimates the determinants of homeownership.

In contrast to regression models, unobserved heterogeneity in duration models is not absorbed into an error term and leads to an estimation bias. Therefore, we use a finite mixture approach to control for potential unobserved heterogeneity and its correlation with unobserved determinants of the selection in public housing (Heckman and Singer, 1984).

\section{$2.1 \quad$ Econometric Model}

As noted by Boehm and Schlottmann (2004, 2009), homeownership is not a single period decision, but a dynamic process which requires the constitution of a downpayment. To account for this, we use a duration analysis to capture the effect of household's characteristics and preceding tenure on age at first-time homeownership.

The proportional hazard duration model is particularly popular in the literature because it allows one to consistently estimate a baseline hazard non-parametrically. In the case of homeownership however, it may cause some identification issues due to the difficulty to capture the behaviour at the tail of the distribution. Therefore, we use a parametric log-normal model.

In a duration model of homeownership attainment, the hazard function $\lambda(t)$ is the probability to access homeownership at time $t+d t$ conditional on being tenant at date $t$. The hazard function can be written as:

$$
\lambda(t)=\frac{1}{\sigma t} \phi\left(\frac{\log (t)-\left(Z \gamma+\alpha p+\nu_{h}\right)}{\sigma}\right) /\left(1-\Phi\left(\frac{\log (t)-\left(Z \gamma+\alpha p+\nu_{h}\right)}{\sigma}\right)\right)
$$


with $\phi$ the density function of the normal law and $\Phi$ its cumulative distribution function, $Z$ a vector of observed characteristics, $p$ a dummy for the previous tenure being public housing, $\alpha$ the parameter of interest, $\gamma$ a vector of parameters to be estimated, $\nu_{h}$ an idiosyncratic term accounting for unobserved variables and $\sigma$ the standard deviation. Note that $\nu_{h}$ will be assumed to be correlated with a similar term in the public housing equation. Using the hazard function, one can derive the density, $f(t)$ and the survival function, $S(t)$ which enter in the sample loglikelihood:

$$
\ell_{h}\left(t \mid Z, p, \gamma, \nu_{h}\right)=\sum_{i=1}^{N}\left[\left(1-\delta_{i}\right) \log f\left(t_{i} \mid Z_{i}, p_{i}, \gamma, \nu_{h i}\right)+\delta_{i} \log S\left(t_{i} \mid Z_{i}, p_{i}, \gamma, \nu_{h i}\right)\right]
$$

with $\delta_{i}=0$ for uncensored observations (households attaining homeownership during the observation period) and $\delta_{i}=1$ for censored observations (still renters at the end of the observation period).

We next consider that the probability of being previously in public housing $p$ ( $p=1$ if the former tenure was public housing and $p=0$ otherwise) follows a logit specification with $\nu_{p}$ an idiosyncratic term accounting for unobserved traits:

$$
\begin{aligned}
& \operatorname{Pr}\left(p=1 \mid X, \nu_{p}\right)=P_{p}=\frac{\exp \left(X \beta+\nu_{p}\right)}{1+\exp \left(X \beta+\nu_{p}\right)} \\
& \operatorname{Pr}\left(p=0 \mid X, \nu_{p}\right)=1-P_{p}=1-\frac{\exp \left(X \beta+\nu_{p}\right)}{1+\exp \left(X \beta+\nu_{p}\right)}
\end{aligned}
$$

The corresponding sample log-likelihood is:

$$
\ell_{p}\left(p \mid X, \beta, \nu_{p}\right)=\sum_{i=1}^{N} p_{i} \log \left(P_{p i}\right)+\left(1-p_{i}\right) \log \left(1-P_{p i}\right)
$$

We control for unobserved heterogeneity by adopting the non-parametric approach proposed by Heckman and Singer (1984). This method consists of assuming the existence of several types of individuals, each characterized by specific values of parameters $\nu_{h}$ and $\nu_{p}$ that affect public 
housing tenancy and age at first-time homeownership. The unobserved characteristics $\nu_{h}$ and $\nu_{p}$ are assumed to follow a discrete bivariate distribution with mass points whose locations are to be estimated. The number of mass points $K$ will be chosen based on a goodness of fit criteria. There are thus $2^{K}$ types of individuals given by the combinations of $K$ mass points, and $2^{K}-1$ probabilities to belong to one given type, to be estimated.

Finally, the joint log-likelihood of the two-equations model is:

$$
\ell \ell\left(t, p \mid Z, X, \beta, \gamma, \nu_{h}, \nu_{p}\right)=\int_{\nu_{h}} \int_{\nu_{p}} \ell_{h}\left(t \mid Z, p, \alpha, \gamma, \nu_{h}\right) * \ell_{p}\left(p \mid X, \beta, \nu_{p}\right) d G\left\{\nu_{h}, \nu_{p}\right\}
$$

Although our preferred specification includes unobserved heterogeneity, we will also provide the results of the model without unobserved heterogeneity using a two-step estimation.

The covariates in these equations relate to the demographic situation of the household (household head gender, marital status, number of children, citizenship) and its permanent income (education and income decile). We further account for a temporal effect by including six dummies for different time periods. These variables are listed in Table 4 .

\subsection{Identification}

The selection of agents into public housing induces an endogeneity in the determinants and the timing of homeownership. Therefore, we use an IV strategy.

In the housing literature, authors have often used aggregate-level instruments, such as the regional share of homeowners in van Leuvensteijn and Koning (2004); Munch et al. (2006) and Munch et al. (2008).

To study the effect of public housing on unemployment in France, Dujardin and GoffetteNagot (2009) use the percentage of public housing at the city level as an instrument. The underlying idea is that the variation in the supply of public housing across cities may create city-level variation in the probability of being in public housing.

Following this idea, we use the share of public tenants among renters at the urban area level 
as instrument. For obvious reasons, the share of public housing is expected to influence the probability to have a spell in public housing. In the rest of this section, we will argue that the share of public tenants is uncorrelated with our variable of interest, the age at first-time homeownership. Since we do not have an alternative instrument, that could have allowed us to perform an exogeneity test, we provide several reasoning that support our exogeneity claim.

First, a source of correlation between our instrument and our variable of interest is a potential sorting of individuals into cities with high share of public housing. We argue that this type of sorting is very unlikely since the stock of public housing is not informative of the supply of vacant public housing. Furthermore, the bias implied by this sorting, if any, would induce a negative effect of public housing on age at first-time homeownership, since households with high preferences for public housing would attain homeownership later or never, and would be concentrated in the cities with high rates of public housing. Yet, as our results show, we obtain an opposite effect of public housing on homeownership attainment. Hence, if the instrument was to bias the estimate, this would not in any case induce our result.

Second, the correlation between the share of public housing in the urban area and the characteristics of the local market for owner-occupied homes may be of concern. Using the share of public housing among rental housing and not among the whole housing stock limits the risk of correlation between the instrument and the share of owner-occupied homes. Since the weig(ht of public housing among rental housing varies greatly across French urban areas, from $10 \%$ to $76 \%$ with a mean at around $40 \%$, this provides a source of variation that is likely to break up the relationship between the share of public housing and the rate of owner-occupied housing.

Finally, we support this informal assessment of our instrumental variable with a test showing the absence of any statistical correlation between our instrument and age at first-homeownership. To do so, we estimate the equation of age at first-time homeownership including three different characteristics of the housing stock in the urban area: the share of owner-occupied housing in 
the housing stock, the share of public housing in the housing stock, and the share of public housing in the tenant-occupied housing stock.

Table 1 shows that all these characteristics have the appropriate effect: ceteris paribus, living in an urban area with a large share of owner-occupied housing decreases age at first-time homeownership, whereas the opposite holds true for the share of public housing, when measured relatively to the whole housing stock. In contrast, the last column of Table 1 shows that the share of public housing in the tenant-occupied housing stock has no significant effect on age at first-time homeownership, suggesting the conditional exogeneity of our instrumental variable.

Table 1: The impact of local housing market characteristics on homeownership

\begin{tabular}{lrrr}
\hline Instruments & $\begin{array}{r}\text { Age at first-time } \\
\text { homeownership }\end{array}$ & $\begin{array}{r}\text { Age at first-time } \\
\text { homeownership }\end{array}$ & $\begin{array}{r}\text { Age at first-time } \\
\text { homeownership }\end{array}$ \\
\cline { 2 - 4 }$\%$ of homeowners in the housing stock & $0.33^{* * *}(0.05)$ & & \\
$\%$ of public tenants in the housing stock & & $-0.292^{* * *}(0.07)$ & $-0.17(0.11)$ \\
$\%$ of public tenants among renters & & YES & YES \\
Controls for household characteristics & YES & 3,773 & 3,773 \\
Observations & 3,773 &
\end{tabular}

Notes: i) The estimations are run on our main sample, defined in section 3. They include controls for the following household characteristics: household head gender, living in couple, number of children, citizenship, education, income decile. Housing stock characteristics are measured based on 1999 Census data. ii) Standard errors clustered on urban areas between parentheses. ${ }^{* * *},{ }^{* *}$ and ${ }^{*}$ indicate significance at the $1 \%, 5 \%$ and $10 \%$ level respectively.

\section{Data}

Our estimation uses data from the French Housing Survey (FHS). The FHS is conducted every four years since 1955 on large and representative samples of the French housing stock. The survey provides both the characteristics of the housing (tenure, number of rooms, floor area, comfort level) and the characteristics of the households living in these housing units (socio-demographics, income, labor-market situation). Moreover, it includes some retrospective information, in particular, the year of arrival in the dwelling and the characteristics of the former dwelling if a mobility occurs in the four preceding years. Table 2 reports the mobility of public tenants over our period of study. 
Table 2: Descriptive statistics on transitions between public housing and homeownership

\begin{tabular}{|c|c|c|c|c|c|c|}
\hline & FHS 1984 & FHS 1988 & FHS 1992 & FHS 1996 & FHS 2002 & FHS 2006 \\
\hline $\begin{array}{l}\text { Annual mobility rate } \\
\text { of } \mathrm{PH} \text { tenants }\end{array}$ & 8.1 & 7.4 & 7.8 & 7.2 & 7.1 & - \\
\hline \multicolumn{7}{|c|}{ Transition of PH tenants (\% of public housing tenants in t- 4 ) } \\
\hline to $\mathrm{PH}$ & 32.9 & 40.0 & 41.2 & 45.8 & 44.4 & 53.0 \\
\hline to homeownership & 47.7 & 41.9 & 32.5 & 30.8 & 31.7 & 27.1 \\
\hline \multicolumn{7}{|c|}{ Previous tenure of first-time homeowners (\% of new homeowners in $t$ ) } \\
\hline in $\mathrm{PH}$ & 31.1 & 29.0 & 23.9 & 24.3 & 24.8 & 20.4 \\
\hline in private renting & 57.8 & 60.1 & 64.8 & 65.2 & 66.6 & 69.3 \\
\hline
\end{tabular}

i) The mobility rate is computed as the ratio of the number of public tenants who moved during the period between two surveys to the number of public tenants in the first of these surveys and is then converted to annual rates. The transitions of public housing tenants are computed based on mobile households of which tenure was public housing four years before the survey. First-time homeowners are mobile households that were not homeowners four years before the survey and are homeowners at the survey. ii) Source: French Housing Survey 1984, 1988, 1992, 1996, 2002, 2006.

Since mobile agents are a non-random sample of the population, using the subsample of mobile agents, with known previous tenure, will cause a sample selection bias. To avoid this bias, but still be able to study the impact of public housing with a backward perspective that is suitable to the analysis of a housing policy, we opted for the pseudo-panel approach described in the next subsection.

\subsection{Pseudo-Panel Approach}

Even though the FHS is not a panel data, it is repeated every four years on a representative sample. Hence, using these repeated cross-sections, we can use a set of tracking conditions to impute the tenure of the previous dwelling for the households surveyed in 2006, but who arrive in their housing before 2002 (previous tenure being unreported in this case). The idea to use several cross-sections to recover individual transitions is commonly referred to as a pseudo-panel approach and was initially developed by Deaton (1985). In practice, we improve the algorithm of Browning et al. (1985) by taking into account the specificities of the local housing market. That is, in addition to household characteristics, we include also urban area and housing characteristics 
to match households between the 2006 and older FHS.

The 2006 FHS records 31,069 households of which head is aged from 18 to 75 in metropolitan France. Table 3 provides the arrival dates of these households depending on tenure. This table shows in particular that households mobile in the four preceding years, for whom the previous tenure is known, account for only a third of the sample. We use the pseudo-panel approach to impute the previous dwelling tenure for those who had a mobility between 1979 and 2001 using the 1984, 1988, 1992, 1996 and 2002 FHS. As a consequence, we are not able to recover the former tenure of households who made a mobility before 1979, $(2,201$ households corresponding to $9.2 \%$ of the 2006 FHS sample). The exclusion of long-time public tenants might bias our estimation, as these households are precisely those who never achieved homeownership. As a robustness check, we show in section 4.3 the results of the model including those individuals.

Table 3: Mobility year by tenure

\begin{tabular}{lccccc}
\hline Period of mobility & \multicolumn{5}{c}{ Tenure } \\
\cline { 2 - 6 } & $\begin{array}{c}\text { Home- } \\
\text { ownership }\end{array}$ & $\begin{array}{c}\text { Private } \\
\text { renting }\end{array}$ & $\begin{array}{c}\text { Public } \\
\text { Housing }\end{array}$ & Other & Total \\
\hline Before 1979 & 14.8 & 1.5 & 6.0 & 5.0 & 9.2 \\
$1979-1983$ & 8.4 & 1.2 & 4.3 & 4.0 & 5.6 \\
$1984-1987$ & 7.7 & 1.4 & 5.2 & 4.1 & 5.5 \\
$1988-1991$ & 8.2 & 2.4 & 6.0 & 6.0 & 6.2 \\
$1992-1997$ & 14.7 & 8.1 & 14.6 & 13.6 & 13.0 \\
$1998-2002$ & 24.1 & 25.7 & 29.7 & 25.5 & 25.8 \\
$2003-2006$ & 22.1 & 59.7 & 34.2 & 41.8 & 34.8 \\
\hline Total & 50.2 & 25.4 & 21.7 & 2.8 & 100.0 \\
\hline Notes: i) FHS 2006. 32,069 households in metropolitan France, head \\
aged 18 to 75. ii) The "other" category consists of tenant farmers \\
and households housed for free by their family or employer.
\end{tabular}

The pseudo-panel procedure consists of matching households from the 2006 FHS to relevant households observed in the previous FHS, depending on the year of their housing transition. The matching criteria is a vector defined by the following variables: urban area, year of arrival, citizenship in three categories (French, French by naturalization, Foreign), education in three categories (Drop-out, High-School, College), housing floor area in four categories (- 40 , 40-69, $70-99,+100 \mathrm{sq} \mathrm{m}$ ), tenure after the residential mobility in four categories (homeowner, private 
tenant, public tenant, other tenure, that housed for free by parents or employer). ${ }^{3}$ In cases of an unsuccessful match, we adjust the year of arrival by one year.

Applying this procedure, we succeed in recovering 1,340 household transitions from FHS 2002, 449 from FHS 1996, 356 from FHS 1992, 402 from FHS 1988, and 428 from FHS 1984. Note that using the urban area dummy as a matching criteria strongly reduces the number of successful matches, but seems important to account for local housing market conditions.

Our matching procedure has two downsides. First, since the match fails for some households, recently-moving households are still overrepresented in the resulting sample. Second, the matching rate is high both in the biggest urban areas and in rural areas, as the latter is clustered into a single large category. As a consequence, households in Paris represent $47.7 \%$ of the successful matches, to be compared to $23 \%$ in the original 2006 FHS sample, while households in rural France account for $26 \%$ of the successful matches, to be compared with $10 \%$ in the original sample. Furthermore, there are only 78 urban areas in our final sample instead of 326 in the original sample.

We deal with the two issues by reducing the subsample of recent movers using a simple random sampling method. After the procedure, we also exclude 1151 households of which previous tenure was homeownership, since our focus is on first-time homeownership. This leaves us with a final sample composed of 3,773 households. ${ }^{4}$

\footnotetext{
${ }^{3}$ There are 326 urban areas in the original sample with population ranging from 8,000 to 11,174,743 for Paris

${ }^{4}$ To check the robustness of our sample, we ran several tests assessing the difference between the characteristics of the samples of successfully matched households and unmatched households. Our tests conclude that there is no significant difference between the two samples in terms of mean income and proportion of mobile individuals per year (results are available upon request). Second, there may be a concern about the accuracy of our predicted former tenure. As a robustness check, we selected randomly half of the recent movers from the 2006 FHS (for whom the preceding tenure is known but is here assumed not to be), used the matching algorithm for matching these households to other households within the 2006 FHS sample to obtain a predicted previous tenure and compared the real to the predicted former tenure. We report $85 \%$ of correct answers. For $11 \%$ of the sample, we do not predict a spell in public housing while they had one, and for $4 \%$ we incorrectly report a spell in public housing. These figures show that our matching algorithm performs reasonably well in predicting former tenure. Moreover, the measurement error induced by the use of the pseudo-panel approach to recover the preceding tenure is likely to reduce the difference in the time before first-homeownership attributed to each type of renters, and therefore to reduce the estimated effect of public housing.
} 


\section{Results}

\subsection{Sample Statistics}

Our working sample is composed of 3,773 households described in Table $4.41 \%$ of this sample consists of recent movers, 25\% moved between 1998-2002 and each of the other periods of mobility account for roughly $10 \%$ of the sample. The income distribution of the sample is similar to that of the general population. 27.1 of the sample consists of households who were public tenants and $64.6 \%$ were private tenants. $46.4 \%$ of individuals achieved first-time homeownership during the observation period. Note that this proportion of homeowners in our sample is lower than the $57.5 \%$ observed in the 2006 FHS because of the first-time homeownership restriction.

Table 5 reports the transition matrix during the period. $25.2 \%$ of transitions into first-time homeownership originate from public housing, $66 \%$ from private renting and $8.8 \%$ from other tenures. Public tenants are as likely to move to another public housing as to buy a house. Transitions from public housing to private renting are less frequent. The other transitions observed in the sample consist mainly of moves within private renting ( $20.6 \%$ of the sample) and within public renting ( $11.6 \%$ of the sample)

Table 6 presents homeowners' characteristics depending on whether they were in public housing previously. $83 \%$ of current homeowners live with a partner, their families have more children and about $5 \%$ of them are immigrants. A third of them achieved homeownership before age 30, and almost another third between 30 and 35. Compared to other homeowners, households who bought a house after a spell in public housing have a lower educational level $(74.1 \%$ with less than high school degree against $51.9 \%$ for the others) and a lower income level $(43.6 \%$ are in the first five deciles against $35.2 \%$ for the others). Despite these clear-cut differences between the two types of homeowners, the sample statistics do not show any significant differences in terms of age when attaining homeownership. Given the low income of public tenants, we can suspect that these households would have not achieved homeownership, or at a substantially higher age 
Table 4: Sample summary statistics

\begin{tabular}{|c|c|c|c|c|}
\hline Variables & Mean & Std dev. & Min & $\operatorname{Max}$ \\
\hline Female & 0.347 & 0.476 & 0 & 1 \\
\hline Living in partnership & 0.662 & 0.473 & 0 & 1 \\
\hline Number of children & 1.173 & 1.208 & 0 & 10 \\
\hline \multicolumn{5}{|l|}{ Age } \\
\hline Less than 30 & 0.089 & 0.285 & 0 & 1 \\
\hline from 30 to 39 & 0.316 & 0.465 & 0 & 1 \\
\hline from 40 to 49 & 0.298 & 0.457 & 0 & 1 \\
\hline from 50 to 64 & 0.253 & 0.436 & 0 & 1 \\
\hline More than 65 & 0.030 & 0.201 & 0 & 1 \\
\hline \multicolumn{5}{|l|}{ Citizenship } \\
\hline French at birth & 0.892 & 0.311 & 0 & 1 \\
\hline French by naturalization & 0.035 & 0.184 & 0 & 1 \\
\hline Foreign & 0.073 & 0.261 & 0 & 1 \\
\hline \multicolumn{5}{|l|}{ Education } \\
\hline Less than High School Degree & 0.603 & 0.489 & 0 & 1 \\
\hline High School Degree & 0.094 & 0.292 & 0 & 1 \\
\hline More than High School Degree & 0.303 & 0.460 & 0 & 1 \\
\hline \multicolumn{5}{|l|}{ Income by decile } \\
\hline $1^{\text {st }}$ decile & 0.112 & 0.316 & 0 & 1 \\
\hline $2^{\text {nd }}$ decile & 0.100 & 0.300 & 0 & 1 \\
\hline $3^{r d}$ decile & 0.098 & 0.297 & 0 & 1 \\
\hline $4^{h}$ decile & 0.108 & 0.310 & 0 & 1 \\
\hline $5^{\text {th }}$ decile & 0.104 & 0.305 & 0 & 1 \\
\hline $6^{\text {th }}$ decile & 0.101 & 0.302 & 0 & 1 \\
\hline $7^{\text {th }}$ decile & 0.092 & 0.289 & 0 & 1 \\
\hline $8^{\text {th }}$ decile & 0.101 & 0.301 & 0 & 1 \\
\hline $9^{\text {th }}$ decile & 0.095 & 0.293 & 0 & 1 \\
\hline $10^{\text {th }}$ decile & 0.090 & 0.286 & 0 & 1 \\
\hline \multicolumn{5}{|l|}{ Previous tenure } \\
\hline Private tenants & 0.646 & 0.445 & 0 & 1 \\
\hline Public tenants & 0.271 & 0.478 & 0 & 1 \\
\hline Others & 0.083 & 0.276 & 0 & 1 \\
\hline \multicolumn{5}{|l|}{ Tenure } \\
\hline Homeowners & 0.464 & 0.499 & 0 & 1 \\
\hline Private tenants & 0.253 & 0.434 & 0 & 1 \\
\hline Public tenants & 0.253 & 0.435 & 0 & 1 \\
\hline Others & 0.030 & 0.172 & 0 & 1 \\
\hline \multicolumn{5}{|l|}{ Year of last mobility } \\
\hline 1979-1984 & 0.086 & 0.280 & 0 & 1 \\
\hline $1985-1988$ & 0.091 & 0.287 & 0 & 1 \\
\hline 1988-1992 & 0.066 & 0.248 & 0 & 1 \\
\hline 1993-1997 & 0.093 & 0.291 & 0 & 1 \\
\hline 1998-2002 & 0.251 & 0.434 & 0 & 1 \\
\hline $2003-2006$ & 0.413 & 0.493 & 0 & 1 \\
\hline$\%$ of $\mathrm{PH}$ among rental housing in the urban area & 0.379 & 0.099 & 0.140 & 0.661 \\
\hline Observations & \multicolumn{4}{|c|}{3,773} \\
\hline
\end{tabular}

if they had not benefited from low rent levels while tenants. The income distribution of public tenants who became homeowners is not very different from that of the whole population. In 
Table 5: Sample tenure transitions

\begin{tabular}{lccccc}
\hline Former tenure & \multicolumn{5}{c}{ Current tenure } \\
\cline { 2 - 6 } & Homeownership & Private renting & Public housing & Other & Total \\
\hline Private renting & 66.0 & 81.7 & 46.9 & 50.0 & 64.7 \\
Public housing & 25.2 & 12.2 & 45.7 & 23.3 & 27.0 \\
Other & 8.8 & 6.0 & 7.4 & 26.7 & 8.3 \\
Total & 100.0 & 100.0 & 100.0 & 100.0 & 100.0 \\
\hline Share of total sample & 46.2 & 25.4 & 25.3 & 3.1 & 100.0 \\
\hline
\end{tabular}

contrast, public housing renters who made a transition to private renting (column 3 of Table 6) are much more concentrated in the lowest income deciles $(46.8 \%$ of them are in the first three deciles).

To estimate the true effect of a spell in public housing on the dynamics to homeownership, we need to control for household characteristics, including unobserved ones.

\subsection{Estimation Results}

In the following subsections, we present several specifications aimed at carefully highlighting the impact of the different features of our model. First, we present results of single duration models of homeownership before turning to the two-equations model to estimate the effect of public housing on homeownership accounting for endogeneity of previous tenure.

\subsubsection{Single Duration Model}

Table 7 presents three different specifications of the single duration model of homeownership. The first specification (column 1) includes only exogenous covariates. The second controls for a potential spell in public housing without accounting for its endogeneity (column 2), while the third includes unobserved heterogeneity (column 3). The comparison between the former and the latter provides a simple test of the importance of unobserved heterogeneity.

The effect of the covariates on the expected duration before homeownership attainment are presented. Therefore, a positive (negative) parameter indicates that the specific variable increases (decreases) age at first-time homeownership. 
Table 6: Sample characteristics depending on current and previous tenure

\begin{tabular}{|c|c|c|c|c|c|}
\hline \multirow[b]{2}{*}{ Previous spell in public housing } & \multicolumn{2}{|c|}{ Homeowners } & \multicolumn{2}{|c|}{ Other tenures } & \multirow[t]{2}{*}{ All } \\
\hline & yes & no & yes & no & \\
\hline Female & 27.1 & 24.1 & 45.4 & 42.4 & 34.8 \\
\hline Living with partner & 83.6 & 83.7 & 47.0 & 48.4 & 66.6 \\
\hline Number of children & 1.5 & 1.3 & 1.2 & 0.9 & 1.2 \\
\hline \multicolumn{6}{|l|}{ Citizenship } \\
\hline French at birth & 94.1 & 96.0 & 84.5 & 83.0 & 89.0 \\
\hline French by naturalization & 3.2 & 1.8 & 6.0 & 4.3 & 3.6 \\
\hline Foreign citizenship & 2.7 & 2.2 & 9.5 & 12.7 & 7.4 \\
\hline \multicolumn{6}{|l|}{ Education } \\
\hline Less than high school degree & 74.1 & 51.9 & 77.3 & 57.1 & 60.4 \\
\hline High school degree & 7.3 & 9.0 & 9.3 & 10.3 & 9.4 \\
\hline More than high school degree & 18.6 & 39.1 & 13.4 & 32.5 & 30.2 \\
\hline \multicolumn{6}{|l|}{ Income by Decile } \\
\hline $1^{\text {st }}$ decile & 3.6 & 3.8 & 17.7 & 17.4 & 11.2 \\
\hline $2^{\text {nd }}$ decile & 8.4 & 5.2 & 16.4 & 12.7 & 10.0 \\
\hline $3^{r d}$ decile & 10.7 & 6.2 & 12.7 & 10.7 & 9.8 \\
\hline $4^{h} t$ decile & 10.2 & 9.7 & 13.1 & 11.0 & 10.8 \\
\hline $5^{\text {th }}$ decile & 10.7 & 10.3 & 10.5 & 10.6 & 10.4 \\
\hline $6^{\text {th }}$ decile & 13.2 & 11.1 & 8.9 & 9.1 & 10.1 \\
\hline $7^{\text {th }}$ decile & 10.7 & 11.1 & 6.2 & 8.1 & 9.2 \\
\hline $8^{\text {th }}$ decile & 12.5 & 13.6 & 6.2 & 7.7 & 10.1 \\
\hline $9^{\text {th }}$ decile & 12.7 & 12.5 & 5.2 & 7.7 & 9.5 \\
\hline $10^{t h}$ decile & 7.3 & 16.5 & 3.1 & 5.0 & 9.0 \\
\hline \multicolumn{6}{|l|}{ Age at first-time homeownership } \\
\hline Less than 30 years & 33.9 & 33.6 & - & - & - \\
\hline $30-35$ years & 30.9 & 30.0 & - & - & - \\
\hline $36-40$ years & 15.7 & 15.0 & - & - & - \\
\hline $41-45$ years & 9.6 & 8.7 & - & - & - \\
\hline $46-50$ years & 4.3 & 5.1 & - & - & - \\
\hline $51-55$ years & 3.0 & 2.9 & - & - & - \\
\hline $56-60$ years & 1.8 & 2.5 & - & - & - \\
\hline $60-65$ years & 0.2 & 1.5 & - & - & - \\
\hline More than 65 years & 0.7 & 0.8 & - & - & - \\
\hline Observations & 440 & 1,305 & 581 & 1,451 & 3,773 \\
\hline
\end{tabular}

The main difference between the three specifications is the effect of income. When we do not include unobserved heterogeneity, the coefficients indicate a counter-intuitive result; that is, low income households achieve homeownership sooner. However, this result is reversed with the introduction of unobserved heterogeneity, with richer households attaining homeownership more rapidly. We suspect unobserved heterogeneity to capture the heterogeneity in homeownership strategy with regard to housing characteristics. Some households, particularly among highincome households, might buy larger houses, and achieve homeownership later in their life-cycle. Introducing unobserved heterogeneity might control this effect, alleviating the omitted variable 
Table 7: Single duration model of age at first-time homeownership

\begin{tabular}{|c|c|c|c|}
\hline Variables & $\begin{array}{l}\text { Without unobserved } \\
\text { heterogeneity; } \\
\text { spell in PH not included } \\
\text { (1) }\end{array}$ & $\begin{array}{l}\text { Without unobserved } \\
\text { heterogeneity; } \\
\text { spell in PH included } \\
(2)\end{array}$ & $\begin{array}{l}\text { With unobserved } \\
\text { heterogeneity; } \\
\text { spell in } \mathrm{PH} \text { included } \\
(3)\end{array}$ \\
\hline Spell in public housing & & $0.023^{* *}(0.01)$ & $0.022^{* *}(0.01)$ \\
\hline Female & $-0.010 \quad(0.01)$ & $-0.011 \quad(0.01)$ & $-0.011 \quad(0.01)$ \\
\hline Living with partner & $0.012 \quad(0.01)$ & $0.012 \quad(0.01)$ & 0.014 \\
\hline Mean number of children & $0.004 \quad(0.004)$ & $(0.01)$ & $0.002 \quad(0.01)$ \\
\hline \multicolumn{4}{|l|}{ Citizenship } \\
\hline French at birth & Reference & Reference & Reference \\
\hline French by naturalization & $0.054^{* *}(0.02)$ & $0.053^{* *}(0.02)$ & $0.059^{* * *}(0.01)$ \\
\hline Foreign citizenship & $0.039 * * *(0.01)$ & $0.041 * * *(0.01)$ & $0.061 * * *(0.01)$ \\
\hline \multicolumn{4}{|l|}{ Diplomas } \\
\hline Less than high school degree & $0.162^{* * *}(0.02)$ & $0.161^{* * *}(0.02)$ & $0.174^{* * *}(0.02)$ \\
\hline High school degree & Reference & Reference & Reference \\
\hline University degree & $-0.011 \quad(0.01)$ & $-0.009 \quad(0.01)$ & $-0.112^{* * *}(0.01)$ \\
\hline \multicolumn{4}{|l|}{ Income by decile } \\
\hline $1^{\text {st }}$ decile & $-0.097^{* * *}(0.02)$ & $-0.097 * * *(0.02)$ & $0.131^{* * *}(0.02)$ \\
\hline $2^{\text {nd }}$ decile & $-0.070 * * *(0.02)$ & $-0.071^{* * *}(0.02)$ & $0.109^{* * *}(0.02)$ \\
\hline $3^{\text {rd }}$ decile & $-0.066^{* * *}(0.02)$ & $-0.067^{* * *}(0.02)$ & $0.003 \quad(0.02)$ \\
\hline $4^{t h}$ decile & $-0.041^{* * *}(0.02)$ & $-0.041^{* * *}(0.02)$ & $0.011 \quad(0.02)$ \\
\hline $5^{\text {th }}$ decile & $-0.051^{* *}(0.02)$ & $-0.051^{* * *}(0.02)$ & $(0.02)$ \\
\hline $6^{\text {th }}$ decile & Reference & Reference & Reference \\
\hline $7^{\text {th }}$ decile & $-0.004(0.02)$ & $0.004(0.02)$ & $0.007 \quad(0.02)$ \\
\hline $8^{\text {th }}$ decile & $0.049(0.02)$ & $0.048^{* *}(0.02)$ & $-0.075 * * *(0.02)$ \\
\hline $9^{t h}$ decile & $0.065^{* *}(0.02)$ & $0.065^{* *}(0.03)$ & $-0.091^{* * *}(0.02)$ \\
\hline $10^{t h}$ decile & $0.196^{* * *}(0.04)$ & $0.197 * * *(0.04)$ & $-0.101^{* * *}(0.02)$ \\
\hline \multicolumn{4}{|l|}{ Time dummies } \\
\hline 1979-1983 & Reference & Reference & Reference \\
\hline 1984-1987 & $-0.223^{* * *}(0.02)$ & $-0.222^{* * *}(0.02)$ & $-0.221^{* * *}(0.02)$ \\
\hline 1988-1991 & $-0.036^{* * *}(0.01)$ & $-0.037^{* * *}(0.01)$ & $-0.035^{* * *}(0.01)$ \\
\hline 1992-1996 & $-0.083^{* * *}(0.02)$ & $-0.081^{* * *}(0.02)$ & $-0.082^{* * *}(0.02)$ \\
\hline 1997-2001 & $-0.159^{* * *}(0.01)$ & $-0.157^{* * *}(0.02)$ & $-0.158 * * *(0.02)$ \\
\hline 2002-2006 & $-0.303^{* * *}(0.01)$ & $-0.301^{* * *}(0.02)$ & $-0.302^{* * *}(0.02)$ \\
\hline \multicolumn{4}{|l|}{ Probability masses } \\
\hline$P\left(\nu_{h}=\nu_{h 1}\right)$ & - & - & $0.43^{* * *}(0.04)$ \\
\hline \multicolumn{4}{|l|}{ Points of support } \\
\hline$\nu_{h 1}$ & - & - & $2.676^{* * *}(0.32)$ \\
\hline$\nu_{h 2}$ & - & - & $3.523^{* * *}(0.47)$ \\
\hline Observations & 3773 & 3773 & 3773 \\
\hline
\end{tabular}

Standard errors clustered on urban areas between parentheses.

${ }^{* * *},{ }^{* *}$ and ${ }^{*}$ indicate significance at the $1 \%, 5 \%$ and $10 \%$ level respectively.

bias.

As to the effect of public housing accommodation, the naive estimation of the single duration model shows that public housing tenants achieve first-time homeownership later than the others. Given that the descriptive statistics showed that public tenants who buy a house were not older than other new homeowners, this result might be driven by the low transition rate from public 
housing to homeownership. In the next step, we turn to the two-equations model to obtain unbiased estimates of the effect of public housing.

\subsubsection{Two-Equations Model}

Table 8 presents two specifications: a two-step estimation and a simultaneous estimation including unobserved heterogeneity. Columns (1) and (3) present the parameters of the public housing equation, while the determinants of homeownership are displayed in columns (2) and (4). The first specification in columns (1) and (2) provides a benchmark that is useful to characterize the bias due to the omission of unobserved heterogeneity. We comment on the results of our best specification, presented in columns (3) and (4).

Our preferred specification, the one with the lowest BIC, is the model including unobserved heterogeneity as a mixture with two points of support. The locations of the points of support are significant in both equations. Our instrument, the percentage of public housing among renters in the urban area, has a positive effect on the probability to have a spell in public housing.

The probability to have a spell in public housing is higher for single mother households and increases with the number of children, which is consistent with the public housing priority code. The number of children increases the probability to have been housed in public housing previously but increases the age at homeownership achievement. French citizenship has a significant impact on both the probability to have a spell in public housing and age at first-time homeownership. Immigrants have a higher probability to have a spell in public housing. They also generally buy a house later in their life, if ever.

The variables that approximate permanent income (education and current income) have a significant effect in both equations. The probability to have a spell in public housing decreases with income and educational level. The effect is the same for the age at homeownership with high-educated and high-income individuals having the lowest age at homeownership attainment. The comparison of columns (2) and (4) shows that the introduction of unobserved heterogeneity 
Table 8: Two equations model of public housing and age at first-time homeownership

\begin{tabular}{|c|c|c|c|c|}
\hline \multirow[b]{2}{*}{ Variables } & \multicolumn{2}{|c|}{$\begin{array}{l}\text { Two-step estimation } \\
\text { without } \\
\text { unobserved heterogeneity } \\
\text { (1) }\end{array}$} & \multicolumn{2}{|c|}{$\begin{array}{l}\text { Simultaneous estimation } \\
\text { with } \\
\text { unobserved heterogeneity }\end{array}$} \\
\hline & $\begin{array}{r}\text { Public } \\
\text { housing }\end{array}$ & $\begin{array}{r}\text { Age at } \\
\text { homeownership }\end{array}$ & $\begin{array}{r}\text { Public } \\
\text { housing }\end{array}$ & $\begin{array}{r}\text { Age at } \\
\text { homeownership }\end{array}$ \\
\hline Spell in public housing & & $-0.131^{* *}(0.05)$ & & $-0.129 * *(0.04)$ \\
\hline Female & $0.147^{* * *}(0.03)$ & $-0.003 \quad(0.11)$ & $0.145^{* * *}(0.03)$ & $-0.002 \quad(0.10)$ \\
\hline Living with partner & $0.068^{* * *}(0.01)$ & $0.013^{* *}(0.01)$ & $0.056^{* * *}(0.01)$ & $\begin{array}{ll}-0.009 \quad(0.01) \\
\end{array}$ \\
\hline Mean number of children & $0.07^{* * *}(0.02)$ & $0.008^{*}(0.004)$ & $0.07 * *(0.03)$ & $0.007 \quad(0.005)$ \\
\hline \multicolumn{5}{|l|}{ Citizenship } \\
\hline Native & Reference & Reference & Reference & Reference \\
\hline French by naturalization & $0.162 \quad(0.12)$ & $0.064^{* * *}(0.02)$ & $0.153^{* * *}(0.05)$ & $0.076^{* * *}(0.02)$ \\
\hline Foreign citizenship & $-0.326^{* *}(0.12)$ & $0.029 *(0.02)$ & $0.552^{* *}(0.11)$ & $0.049 *(0.03)$ \\
\hline \multicolumn{5}{|l|}{ Diplomas } \\
\hline ¡ high school degree & $0.255^{* * *}(0.09)$ & $0.173^{* * *}(0.02)$ & $0.278^{* * *}(0.09)$ & $0.152^{* * *}(0.02)$ \\
\hline High school degree & Reference & Reference & Reference & Reference \\
\hline University degree & $-0.411^{* * *}(0.12)$ & $-0.025 \quad(0.02)$ & $-0.392^{* * *}(0.12)$ & $-0.105^{* * *}(0.02)$ \\
\hline \multicolumn{5}{|l|}{ Income by decile } \\
\hline $1^{\text {st }}$ decile & $-0.052 \quad(0.11)$ & $-0.102^{* * *}(0.02)$ & $0.209 * * *(0.07)$ & $0.124^{* * *}(0.02)$ \\
\hline $2^{\text {nd }}$ decile & $0.042 \quad(0.06)$ & $-0.069 * *(0.02)$ & $0.152 * * *(0.04)$ & $0.112^{* * *}(0.02)$ \\
\hline $3^{\text {rd }}$ decile & $0.164 *(0.07)$ & $-0.060 * *(0.02)$ & $0.175^{* * *}(0.05)$ & $0.082^{* * *}(0.02)$ \\
\hline $4^{t h}$ decile & $-0.033 \quad(0.08)$ & $-0.043^{* *}(0.02)$ & $0.036 \quad(0.06)$ & $0.054^{* *}(0.02)$ \\
\hline $5^{\text {th }}$ decile & $-0.074 \quad(0.07)$ & $-0.057^{* * *}(0.02)$ & $-0.054 \quad(0.08)$ & $-0.062 \quad(0.06)$ \\
\hline $6^{\text {th }}$ decile & Reference & Reference & Reference & Reference \\
\hline $7^{\text {th }}$ decile & $-0.144^{*}(0.08)$ & $-0.009 \quad(0.02)$ & $-0.151^{* *}(0.07)$ & $-0.007 \quad(0.02)$ \\
\hline $8^{\text {th }}$ decile & $0.005 \quad(0.07)$ & $0.049 * *(0.02)$ & $-0.112 * *(0.05)$ & $-0.069 * *(0.02)$ \\
\hline $9^{t h}$ decile & $0.013 \quad(0.09)$ & $0.067^{* *}(0.03)$ & $-0.109 * *(0.04)$ & $-0.047^{* *}(0.01)$ \\
\hline $10^{t h}$ decile & $-0.316^{* *}(0.10)$ & $0.189^{* * *}(0.04)$ & $-0.316^{* *}(0.10)$ & $-0.195^{* * *}(0.04)$ \\
\hline \multicolumn{5}{|l|}{ Temporal dummies } \\
\hline 1979-1983 & Reference & Reference & Reference & Reference \\
\hline 1984-1987 & $-0.268 \quad(0.07)$ & $-0.241^{* * *}(0.02)$ & $-0.267 \quad(0.07)$ & $-0.248^{* * *}(0.02)$ \\
\hline 1988-1991 & $-0.046^{* * *}(0.11)$ & $-0.039 * * *(0.01)$ & $-0.049 * * *(0.11)$ & $-0.042^{* * *}(0.01)$ \\
\hline 1992-1996 & $-0.394^{* * *}(0.06)$ & $-0.102^{* * *}(0.02)$ & $-0.393^{* * *}(0.06)$ & $-0.111^{* * *}(0.02)$ \\
\hline $1997-2001$ & $-0.349 * * *(0.08)$ & $-0.178 * * *(0.02)$ & $-0.395^{* * *}(0.08)$ & $-0.182^{* * *}(0.02)$ \\
\hline $2002-2006$ & $-0.259 * * *(0.07)$ & $-0.319 * * *(0.02)$ & $-0.352^{* * *}(0.07)$ & $-0.381^{* * *}(0.09)$ \\
\hline$\%$ of $\mathrm{PH}$ among rental housing & $2.90^{* * *}(0.19)$ & & $3.11^{* * *}(0.45)$ & \\
\hline \multicolumn{5}{|l|}{ Probability masses } \\
\hline$p_{11}$ & \multicolumn{2}{|l|}{-} & \multicolumn{2}{|c|}{$0.327 * * *(0.03)$} \\
\hline$p_{12}$ & \multicolumn{2}{|l|}{-} & \multicolumn{2}{|c|}{$0.192^{* * *(0.02)}$} \\
\hline$p_{21}$ & \multicolumn{2}{|l|}{-} & \multicolumn{2}{|c|}{$0.302^{* * *}(0.02)$} \\
\hline \multicolumn{5}{|l|}{ Points of support } \\
\hline$\nu_{h 1}$ & \multicolumn{2}{|l|}{ - } & \multicolumn{2}{|c|}{$3.023^{* * *}(0.32)$} \\
\hline$\nu_{h 2}$ & \multicolumn{2}{|l|}{-} & \multicolumn{2}{|c|}{$3.878^{* * *}(0.47)$} \\
\hline$\nu_{p 1}$ & \multicolumn{2}{|l|}{-} & \multicolumn{2}{|c|}{$1.201^{* * *}(0.24)$} \\
\hline$\nu_{p 2}$ & \multicolumn{2}{|c|}{ - } & \multicolumn{2}{|c|}{$2.568^{* * *}(0.37)$} \\
\hline Observations & \multicolumn{2}{|c|}{3773} & \multicolumn{2}{|c|}{3773} \\
\hline
\end{tabular}

$p_{11}=P\left(\nu_{h}=\nu_{h 1}, \nu_{p}=\nu_{p 1}\right), p_{12}=P\left(\nu_{h}=\nu_{h 1}, \nu_{p}=\nu_{p 2}\right), p_{21}=P\left(\nu_{h}=\nu_{h 2}, \nu_{p}=\nu_{p 1}\right)$

Standard errors clustered on urban areas between parentheses.

***, ${ }^{* *}$ and ${ }^{*}$ indicate significance at the $1 \%, 5 \%$ and $10 \%$ level respectively. 
has the same effect as in the single duration model.

The time-period dummies coefficients are consistent with the decreasing transition rate to homeownership. Our estimates show that age at first-time homeownership decreased significantly at the beginning of the 80 's, that witnessed the growing momentum of the French homeownership promotion policy launched in 1977. Age at first-time homeownership increased in the subsequent years, with the end of some low-interest subsidized mortgages. However, the introduction of a zero-interest mortgage in 1996 (the "Pret a taux zero", see Gobillon and Le Blanc 2008), followed by the decrease in the mortgage interest rate, that allowed young households to increase the length of their mortgages, contributed to a reduction of the age at homeownership at the end of our observation period.

Finally, the spell in public housing, our variable of interest, has a negative effect on age at first-time homeownership. Having a spell in public housing allows some households, ceteris paribus, to access homeownership earlier. The point estimates obtained in the simultaneous estimation with unobserved heterogeneity is slightly lower in absolute value than that of the twostep estimation, consistent with what could be expected once the correlation due to unobserved heterogeneity is taken into account. The standard errors show however that this difference is not significant. This estimate implies that the net balance between the saving effects and the potential negative externalities associated with public housing is positive. Our main result is thus consistent with the idea that the public housing policy allows some households, who would never have become homeowners otherwise, to save more during their spell in public housing, and enable them to buy a house.

\subsection{Robustness Checks}

As explained in subsection 3.1, we performed an adjustment of our sample after the pseudo-panel procedure in order to reproduce the annual mobility rate, as observed on the original 2006 FHS sample. This adjustment consists of reducing the number of recent moving households in the 
sample. We test the sensitivity of our main result to this sample adjustment, by running our estimation on the sample including recent movers that were dropped at the sample adjustment step. The parameter of interest in the estimation on this new sample is -0.447 (standard error 0.098), which is higher in absolute value than the effect estimated on our main working sample. This estimates thus points to an even stronger favorable effect of public housing on the dynamics to homeownership. This change in the point estimate is consistent with the bias induced by the selection into mobility.

Our pseudo-panel method also excludes the less mobile households because our matching procedure does not recover mobilities that occurred before 1979. To assess on the impact of this restriction, we use a new sample with all the households surveyed in the 2006 FHS. The former tenure considered is that of the housing occupied four years before the survey. This is the tenure of previous housing for recent movers and the tenure of current housing for the households which entered their housing before 2002. This presents obviously the downside that the real previous tenure of households who moved before 2002 is ignored. Given this definition of former tenure, our model is estimated on the sample of all households that were not previously homeowners, including non-mobile households. To observe this picture at different points in time over our study period, we perform this estimation for each of the FHS that have been used in the pseudo-panel procedure, thus covering the 1979-2006 period.

The coefficient estimates presented in Table 9 point to a favorable impact of public housing on transitions to homeownership for all the sub-periods. The absolute value of the estimates is high for the 1988 FHS and lower for the subsequent years. This evolution is consistent with the general context of homeownership attainment, as the rise in housing prices that started in France in 1999 probably impacted more strongly low-income households.

In addition, the estimated effects are higher in magnitude than those estimated on the pseudo-panel sample. This can be understood as the consequence of the very frequent moves made by private renters within the private renting sector. On the contrary of private tenants, 
Table 9: Estimation of the two-equations model on all households not previously homeowners

\begin{tabular}{lcccccc}
\hline & $1984 \mathrm{FHS}$ & $1988 \mathrm{FHS}$ & $1992 \mathrm{FHS}$ & $1996 \mathrm{FHS}$ & $2002 \mathrm{FHS}$ & $2006 \mathrm{FHS}$ \\
\hline Spell in public housing & $-0.152^{* * *}$ & $-0.474^{* * *}$ & $-0.296^{* *}$ & $-0.351^{* *}$ & $-0.339^{* *}$ & $-0.151^{*}$ \\
& $(0.076)$ & $(0.115)$ & $(0.127)$ & $(0.153)$ & $(0.132)$ & $(0.08)$ \\
Observations & 15,152 & 16,821 & 22,092 & 15,717 & 14,100 & 18,212 \\
\hline
\end{tabular}

Standard errors clustered on urban areas between parentheses.

${ }^{* * *},{ }^{* *}$ and ${ }^{*}$ indicate significance at the $1 \%, 5 \%$ and $10 \%$ level respectively.

Notes: The estimations are performed on the whole samples of the French Housing Surveys, keeping only households that were not previously homeowners. The existence of a spell in $\mathrm{PH}$ is measured through tenure of the housing occupied four years preceding the survey for recent movers and through tenure of current housing for all other households. Control variables include: gender, living in couple, number of children, citizenship, education, income decile, as well as changes in the family composition, changes in employment situation and inheritance receipt for the 2006 FHS estimation. Previous tenure in public housing is instrumented with the share of public housing among the rental housing stock in the urban area.

public tenants have lower mobility rates, but when they move, they tend to make a transition to homeownership. For example, in the 2006 FHS, mobile public tenants were almost as likely as moving private renters to make a transition to homeownership (27.6\% against $31.9 \%$ for private tenants), despite their lower income level.

\section{Conclusion}

Although public housing is a policy designed to improve the housing conditions of the low-income households, there are very few research on its effects on tenants' outcomes. Our analysis contributes to fill this gap by looking at the effect of public housing accommodation on subsequent homeownership attainment in the French case. Our results suggest that public housing plays an important role in helping some households achieve homeownership. More precisely, compared to private renting, living in public housing speeds up the transition to homeownership. This result does not induce that all public tenants can attain homeownership; some of them, will never be able to accumulate enough wealth to constitute a downpayment. In contrast to other policies toward homeownership, public housing relies on the capacity of the household to accumulate savings. In other words, this "aid" auto-selects the public tenants that are the most able to attain homeownership. As a consequence, one can wonder about the respective benefits of 
mortgage interest deduction policy versus a public housing policy that would subsidize housing expenditures. This aspect of public housing has never been accounted for before.

We believe that our careful methodology provides a reliable estimate of the impact of public housing on the dynamics to homeownership. In the absence of a long-period panel data that would be required to study housing transitions, we developed a pseudo-panel approach. Further, we dealt with the endogeneity of public housing accommodation by using an instrument, that has been shown not to impact age at homeownership. Finally, our econometric model takes unobserved heterogeneity into account.

Our results suggest two types of households in the public housing. Some households might never leave public housing because of an unobserved taste or a high preference for the present. For this type of households, public housing might constitute a trap. For a second type, public housing might, on the contrary, represent a springboard to homeownership by allowing them to save more. Therefore, any assessment of the impact of public housing has to account for unobserved heterogeneity.

Of course, a complete evaluation of the public housing policy would require to quantify the other effects of public housing on its tenants and to compare this indirect form of homeownership aid to other measures promoting homeownership. The efficiency of public housing could for instance be compared to that of mortgage interest deduction measures. In addition, the macroeconomic impact of the supply of public housing on the other parts of the housing market should also be considered. This is beyond the scope of this paper but will deserve attention in future research. 


\section{References}

Boehm, T.P., Schlottmann, A.M., 2004. The dynamics of race, income, and homeownership. Journal of Urban Economics 55, 113 - 130.

Boehm, T.P., Schlottmann, A.M., 2009. The dynamics of homeownership: eliminating the gap between african american and white households. Real Estate Economics 37, 599-634.

Browning, M., Deaton, A., Irish, M., 1985. A profitable approach to labor supply and commodity demands over the life-cycle. Econometrica 53, 503-43.

Currie, J., Yelowitz, A., 2000. Are public housing projects good for kids? Journal of Public Economics 75, 99-124.

Currie, J., Yelowitz, A.S., 1998. Public Housing and Labor Supply. JCPR Working Papers 52. Northwestern University/University of Chicago Joint Center for Poverty Research.

Deaton, A., 1985. Panel data from time series of cross-sections. Journal of Econometrics 30, $109-126$.

Dujardin, C., Goffette-Nagot, F., 2009. Does public housing occupancy increase unemployment? Journal of Economic Geography 9, 823-851.

Fertig, A.R., Reingold, D.A., 2007. Public housing, health, and health behaviors: Is there a connection? Journal of Policy Analysis and Management 26, 831-859.

Gobillon, L., le Blanc, D., 2008. Economic effects of upfront subsidies to ownership: The case of the prêt à taux zéro in France. Journal of Housing Economics 17, 1 - 33 .

de Graaff, T., van Leuvensteijn, M., van Ewijk, C., 2009. Homeownership, Social Renting and Labour Mobility, in: van Leuvensteijn, M., van Ewijk, C. (Eds.), Homeownership and the Labour Market in Europe, Oxford University Press, Oxford, pp. 53-81. 
Heckman, J., Singer, B., 1984. A method for minimizing the impact of distributional assumptions in econometric models for duration data. Econometrica 52, 271-320.

Jacob, B., 2004. Public housing, housing vouchers, and student achievement: Evidence from public housing demolitions in Chicago. American Economic Review 94, 233-258.

LeBlanc, D., Laferrère, A., 2001. The effect of public social housing on households' consumption in france. Journal of Housing Economics 10, 429-455.

van Leuvensteijn, M., Koning, P., 2004. The effect of home-ownership on labor mobility in the Netherlands. Journal of Urban Economics 55, 580-596.

Munch, J.R., Rosholm, M., Svarer, M., 2006. Are homeowners really more unemployed? Economic Journal 116, 991-1013.

Munch, J.R., Rosholm, M., Svarer, M., 2008. Home ownership, job duration, and wages. Journal of Urban Economics 63, 130-145.

Newman, S., Harkness, J., 2002. The long-term effects of public housing on self-sufficiency. Journal of Policy Analysis and Management 21, 21-43.

Reingold, D., Van Ryzin, G., Ronda, M., 2001. Does urban public housing diminish the social capital and labor force activity of its tenants? Journal of Policy Analysis and Management $20,485-504$. 